\title{
Assessment on Potential of Cow Dung Manure in Zea mays Production at Kiwere Village in Iringa Rural District, Tanzania
}

\author{
Washa Bugalama Washa \\ Biological Science Department, Mkwawa College, University of Dar Salaam, Iringa, Tanzania \\ Email: wbugalama@yahoo.com
}

How to cite this paper: Washa, W.B. (2020) Assessment on Potential of Cow Dung Manure in Zea mays Production at Kiwere Village in Iringa Rural District, Tanzania. American Journal of Plant Sciences, 11, 1751-1764.

https://doi.org/10.4236/ajps.2020.1111126

Received: October 9, 2020

Accepted: November 24, 2020

Published: November 27, 2020

Copyright $\odot 2020$ by author(s) and Scientific Research Publishing Inc. This work is licensed under the Creative Commons Attribution International License (CC BY 4.0).

http://creativecommons.org/licenses/by/4.0/

\section{(c) (i) Open Access}

\begin{abstract}
An assessment on potentiality of Cow dung manure in Zea mays production at Kiwere village in Iringa Rural District ( $7^{\circ} 37^{\prime} 17.3^{\prime \prime}$ S, $\left.35^{\circ} 37^{\prime} 48.1^{\prime \prime E}\right)$ was conducted from December 2019 to June 2020. The idea of this assessment was influenced by soil fertility depletion and the fall of Maize production in Iringa region from 1990's. A total of 10 farms, 5 farms for Cow dung manured and 5 for non-manured in which Maize growth was monitored for 6 months. Various parameters as height, width and weight of both Maize plants and Maize fruits were recorded. Soil qualities both chemical and physical characteristics were analysed and recorded but also weather (Temperature, humidity) together with soil $\mathrm{pH}$ were recorded throughout the assessment period. The p-value of $<0.0001(1.03702 \mathrm{E}-07)$ and $<0.0001(2.45684 \mathrm{E}-05)$ for height and width and the highest mineral chemical values in the Cow manured 10 plots indicated that Cow manure not only increase Maize production significantly but also supports the production of soil microbial and hence renewals the soil minerals and soil fertility as well. This is why the soil physical values in the Cow dung manured plots Organic matter, porosity, soil aeration and others were found to be higher and the soil comprised of Sandy Clay Loam. Farmers are strongly advised to use this multipurpose and potential manure in their unfertile soil. Cow manures are easily available in their environment and cheaper.
\end{abstract}

\section{Keywords}

Cow Dung, Manures, Zea mays, Nutrients, Loam Soil 


\section{Introduction}

\subsection{The Botany of Maize (Zea mays)}

Maize is a common name of a plant which is scientifically known as Zea mays as it comes from the genus Zea in the grass family (Poaceae). The species is commonly known as corn through the North American countries. This is a vascular plant, seed plant and flowering plant [1]. The nutritional value per $100 \mathrm{~g}$ of Maize, energy is $360 \mathrm{~kJ}$ ( $86 \mathrm{kcal}$ ), carbohydrates is $18.7 \mathrm{~g}$, fat is $1.35 \mathrm{~g}$, protein is $3.27 \mathrm{~g}$, water is $75.96 \mathrm{~g}$, Zinc is $0.46 \mathrm{mg}$, Phosphorus is $89 \mathrm{mg}$, Potassium is 270 $\mathrm{mg}$, vitamin is C $6.8 \mathrm{mg}$, Iron is $0.52 \mathrm{mg}$ and Magnesium is $37 \mathrm{mg}$ [2]. The morphology of Maize is 1 to 4 meters tall, has approximately 30 leaves, has an erect stalk-like structure, is a meristem, has sheath surrounding the stalk, has expanded blade by blade joint or collar and has nodes and internodes [3]. Leaves are broad and a single leaf, are arranged in two vertical rows on the opposite sides of an axis (distichous), are long, large, and alternate with parallel veins. Roots are fibrous, brace, form at the bottom of the stalk, support the plant and scavenge top levels of soil for moisture and nutrients, are seminal, are nodal originating from a scutellar node, they sustain seedling development by virtue of water intake [3].

Male \& female inflorescence of Maize is located at the different part, male inflorescence is called tassel, female inflorescence is called ear, and maize pollen is dispersion by wind and is an annual plant. Another is a male reproductive part of the corn plant, it consists of several small branches, along which small flowers grow. The flowers release pollen grains, which contain the male sex cell. The ear is the female reproductive part of a corn plant. Ears develop from "shanks", which are stalk-like structures that grow from the plant's leaf nodes. A corn plant may produce many ears, but the uppermost ear will grow to be the largest. The ear consists of a cob, eggs that eventually develop into kernels and silks. Pollination occurs when pollen from the male tassel falls on the female silks [4]. Corn Seed of Maize is a protective sheath enclosing the shoot tip and the embryonic leaves of grasses, the triploid nutritive tissues formed within the embryo seed plants. Stamen is a pollen-producing reproductive organ which is referred to as androecium. Stalk which is also known as filament is the part of the stamen from which the anther develops. Anther is the terminal part of a stamen from which the pollens are produced. Style is a slender part of the pistil, situated between the ovary and stigma. Stigma is a receptive apex of the pistil of a flower on which pollen is deposited, sheath part of leaf originating from the node and running parallel to the culm or stem. Ligule is a membrane located between the Culm and the leaf blade [4].

The life cycle of Maize includes the haploid gametophyte stage, male gametogenesis which is the microspore (pollen grain) and the endosperm and embryo, both of which are products of double fertilization. Corn has a life cycle of 120 to 150 days. It is best to plant after these days. It will grow 3 to 10 feet tall during its cycle. There are several types of kernels to use such as yellow, red, orange, black 
and bronze. For the corn to begin to germinate it has to have lots of water. The kernels must be planted 2 to 3 inches [5].

\subsection{Cow Manure (Cow Dung)}

Cow dung is the west product of bovine animal species (domestic cattle, buffalo and water buffalo). Cow dung is the undigested residue of plant matter and grass which has passed through the animal's gut. The resultant faecal matter is rich in minerals. Colour ranges from greenish to blackish, often darkening soon after exposure to air. Cow dung, which is usually a dark brown color, is often used as manure (agricultural fertilizer). If not recycled into the soil by species such as earthworms and dung beetles, Cow dung can dry out and remain on the pasture, creating an area of grazing land which is unpalatable to livestock [6]. In many parts of the developing world, and in the past in mountain regions of Europe, caked and dried cow dung is used as fuel. Dung may also be collected and used to produce biogas to generate electricity and heat. The gas is rich in methane and is used in rural areas of India and Pakistan and elsewhere to provide a renewable and stable source of electricity. In central Africa, Maasai villages have burned cow dung inside to repel mosquitoes. In cold places, cow dung is used to line the walls of rustic houses as a cheap thermal insulator. Most villagers in India spray fresh cow dung mixed with water in front of the houses to repel insects. It is also dried into cake-like shapes and used as a replacement for firewood [7]. Cow dung is also an optional ingredient in the manufacture of adobe mud brick housing depending on the availability of materials at hand. Cow dung is also known as cow pats, cow pies and cow chips. Cow dung provides food for a wide range of animal and fungus species, which break it down and recycle it into the food chain and into the soil. Cow dung is high in organic materials and rich in nutrients. It contains about 3 percent nitrogen, 2 percent phosphorus, and 1 percent potassium (3-2-1 NPK). In addition, cow manure contains high levels of ammonia and potentially dangerous pathogens. For this reason, it's usually recommended that it be aged or composted prior to its use as cow manure fertilizer [8].

\subsection{Land Elevation, Landform and Soil of Iringa}

Based on the previous report, Iringa land surface elevation ranges from $1300 \mathrm{~m}$ to $2000 \mathrm{~m}$ and the landform ranges from rolling hills to pediments while the parent materials of soils range from basement complex to colluvium or alluvium ([9] FAO, 1984). Iringa is composed of pediments and inselbergs with about $1300 \mathrm{~m}$ to $2000 \mathrm{~m}$ which is confined to interfluves areas within the southern highlands [9]. Some areas of Iringa are still lower being transitional to Mtera basin. The mean annual rainfall in Iringa is $578 \mathrm{~mm}$ and the mean annual temperature is $22.7^{\circ} \mathrm{C}$ [10]. Organic carbon content decreases from $1300 \mathrm{~m}$ to 2000 $\mathrm{m}$ due to the slow decomposition of organic matter at higher altitudes. Soil $\mathrm{pH}$ value decreases with increasing altitude and CEC of clay ranged between 6 and 
21, which seemed well correlated with their elevations [9]. This land and soil status of Iringa is based on 1970 to 1980's investigations when Iringa was among the giant region in Maize production as soil fertility supported the production. After a range of 30 years from the [9] report, the use of industrial fertilizers have depressed the soil fertility in Iringa and the region is no longer giant in Maize production necessitating the use of manures especially Cow dung which can re-add microbial which can initiate and renew the soil nutrients [10]. This research is expected to reveal to what extent is cow manure is potential in renewing the soil fertility and boast the maize production. Will report the present soil status and findings will be presented to farmers, researchers as well as the Government.

\section{Objective of the Study}

The main objective is to assess to potential of Cow manure in Maize production.

\section{Specific Objective}

1) To analyse physical characteristics of soil in 10 plots of manured and non-manured farms.

2) To analyse chemical characteristics of soil in 10 plots of manured and non-manured farms.

3) To examine Maize qualities (height, width and weight) of both Maize plant and Maize fruits in the manured and non-manured soil.

\section{Material and Methods}

\subsection{Investigation Area and Tasks}

An assessment was conducted at Kiwere village ( $\left.7^{\circ} 37^{\prime} 17.3^{\prime \prime} \mathrm{S}, 35^{\circ} 37^{\prime} 48.1^{\prime \prime} \mathrm{E}\right)$ which is located $14 \mathrm{~km}$ west from Iringa centre along Pawaga road but $2 \mathrm{~km}$ south of Ruaha irrigation system at Mgera Ward of Iringa Rural District. The assessment was conducted during rainy season from December 2019 to June 2020. The first task was to identify 5 Maize farms which have nerver added Cow manure since their establishment and other 5 Maize farms in which Cow manure were added 2 to 3 years ago to ensure complete decomposition of the manure so that can be able to release nutrients to the soil but also renear microbios which can assist nitrient fixation into soil. This task was taken at be beggining of rain seaso, December 2019 to January 2020 to ensure that all identified farms are in cultivation progress. A farm was qualified for identification based on 2 criteials one is if a farm was added Cow manure or never added and second a farm should have a size of giving not less than 2 plots of 100 square meters each plot $(10 \times 10) \mathrm{m}$.

The second task was to collect soil sample from each of the 10 farms and take to University of Dar es Salaam for characterization. Soil sampling procedure was conducted based on. Standard methods as per [11]. Soil sampling was conducted on December 2019 to January 2020. A total Tsh. 10,000,000.00 (Ten million shil- 
lings was used for all activities of the research. This was the own sponsorship.

\subsection{Experimental Design}

The experiment was arranged into split-plot design where the manure added farms and farms without manure were treated as main plots while the growth parameters in the plots were treated as sub-plots. This was followed by daily observation of growth parameters (height and width or dbh of maize plant and maize fruit) from seed germination to the maize grain in each of the 10 farms and 20 plots.

\subsection{Recorded Parameters}

1) Weather of Iringa and (Temperature, Humidity) from December 2019 to June 2020 (Table 6).

2) Soil $\mathrm{pH}$ in all of the farms and plots.

3) Obtained soil characteristics.

4) Height and diameter (dbh) of maize plants in the plots.

5) Height and diameter (dbh) of the maize fruit in the plots.

Obtained growth parameters were subjected to statistical analysis.

\subsection{Data Analysis}

Data was analysed according to [12] and P-value was used to determine statistical difference between treatment means and growth parameters of the two treatments (manure added and non-manured) plots (Photography 1-6). Data were summarized into relevant tables and figures to facilitate discussion and recommendation.

\subsection{Tables and Photographs for Collected Data}

Data and other informations collected for analysis and observations were presented in various Tables 1-6.

\section{Results}

Generally, this analysis illustrates two independent sample tests. The Welch's $\mathrm{t}$-test which does not require the assumption of equal variance among the two populations is being used to determine the effect of treatment variables.

\subsection{Growth Parameters between Plots and Treatments}

\subsubsection{Mean Height in Ten Plots}

H0: The means of two maize plants in $\mathrm{cm}$ are equal (The $\mathrm{cm}$ of maize plant associated by manure added farms are equal to $\mathrm{cm}$ of maize plant associated by Non manure farms).

H1: The means of two maize plants are not equal (The $\mathrm{cm}$ of maize plant associated by manure added farms are not equal to $\mathrm{cm}$ of maize plant associated by Non manure farms). 
Table 1. Growth parameters between plots and treatments.

\begin{tabular}{llcc}
\hline & & \multicolumn{2}{c}{ Measurements of maize plants in cm } \\
\cline { 3 - 4 } & & $\begin{array}{c}\text { Mean height } \\
\text { in 10 plots }\end{array}$ & $\begin{array}{c}\text { Mean widths } \\
\text { in 10 plots }\end{array}$ \\
\hline & Farm 1 & 200 & 0.5 \\
Farm 2 & 215 & 0.6 \\
& Farm 3 & 220 & 0.6 \\
& Farm 4 & 208 & 0.5 \\
& Farm 5 & 221 & 0.5 \\
& Mean & 212.8 & 0.54 \\
\hline & Farm 1 & 100 & 0.3 \\
& Farrn 2 & 100 & 0.2 \\
& Farm 3 & 120 & 0.2 \\
\hline Form 4 & 117 & 0.3 \\
& Farm 5 & 102 & 0.2 \\
& Mean & 107.8 & 0.24 \\
\hline
\end{tabular}

Table 2. Growth parameters between plots and treatments.

\begin{tabular}{|c|c|c|c|}
\hline & & \multicolumn{2}{|c|}{ Measurements of maize fruits in $\mathrm{cm}$} \\
\hline & & $\begin{array}{l}\text { Mean height } \\
\text { in } 10 \text { plots }\end{array}$ & $\begin{array}{l}\text { Mean widths } \\
\text { in } 10 \text { plots }\end{array}$ \\
\hline \multirow{6}{*}{ Manure added farms } & Farm 1 & 25 & 0.9 \\
\hline & Farm 2 & 24 & 0.7 \\
\hline & Farm 3 & 26 & 0.8 \\
\hline & Farm 4 & 23 & 0.9 \\
\hline & Farm 5 & 25 & 0.8 \\
\hline & Mean & 24.6 & 0.82 \\
\hline \multirow{6}{*}{ Non-manure farms } & Farm 1 & 1.0 & 0.3 \\
\hline & Farrn 2 & 0.8 & 0.2 \\
\hline & Farm 3 & 0.6 & 0.4 \\
\hline & Farm 4 & 0.9 & 0.4 \\
\hline & Farm 5 & 0.8 & 0.3 \\
\hline & Mean & 0.82 & 0.32 \\
\hline
\end{tabular}

The two sample mean value (variance) are 212.8 (77.7) and 107.8 (97.2). the calculated t-statistic is 17.7 with its associated $p$ value of two tailed statistic of $<0.0001(1.03702 \mathrm{E}-07)$. Since the $\mathrm{p}$-value is less than 0.05 this provides enough 
Table 3. Growth parameters between plots and treatments.

\begin{tabular}{llc}
\hline & & Weight of maize fruits in Kilograms \\
\cline { 2 - 2 } & & Mean Weight in 10 plots \\
& Farm 1 & 0.5 \\
& Farm 2 & 0.3 \\
Fanure added farms 3 & Farm 4 & 0.7 \\
& Farm 5 & 0.5 \\
& Mean & 0.6 \\
& Farm 1 & 0.52 \\
\hline Farm 2 & 0.1 \\
& Farm 3 & 0.04 \\
Farm 4 & 0.1 \\
Farm 5 & 0.2 \\
Mean & 0.3 \\
\hline
\end{tabular}

Table 4. Chemical characteristics of soil (mean for each of the 20 plots).

\begin{tabular}{|c|c|c|c|c|c|c|c|c|c|c|c|}
\hline \multirow[b]{2}{*}{$\begin{array}{l}\text { Main } \\
\text { plots }\end{array}$} & \multirow[b]{2}{*}{ Sub-plots } & \multirow[b]{2}{*}{$\mathrm{pH}$} & \multicolumn{3}{|c|}{$\%$} & \multicolumn{5}{|c|}{ (meq./100g) } & \multirow{2}{*}{$\begin{array}{c}\left(\mathrm{S} \cdot \mathrm{m}^{-1}\right) \\
\mathrm{EC}\end{array}$} \\
\hline & & & $\mathrm{OM}$ & $\mathrm{N}^{-1}$ & $\mathrm{PO}_{3}^{-4}$ & $\mathrm{~K}^{+}$ & CEC & $\mathrm{Na}^{+}$ & $\mathrm{Ca}^{2+}$ & $\mathrm{Mg}^{2+}$ & \\
\hline \multirow{6}{*}{$\begin{array}{c}\text { Manure } \\
\text { added } \\
\text { farms }\end{array}$} & Farm 1 & 7.7 & 28 & 1.0 & 1.7 & 1.4 & 17 & 2.7 & 10.2 & 4.5 & 109 \\
\hline & Farm 2 & 7.2 & 38 & 2.9 & 1.5 & 1.7 & 16 & 3.0 & 11.7 & 6.7 & 170 \\
\hline & Farm 3 & 7.5 & 40 & 2.4 & 1.9 & 2.0 & 20 & 2.5 & 9.8 & 5.8 & 145 \\
\hline & Farm 4 & 7.7 & 52 & 1.1 & 1.8 & 1.9 & 18 & 2.9 & 7.7 & 6.2 & 152 \\
\hline & Farm 5 & 7.7 & 51 & 2.3 & 1.6 & 1.9 & 21 & 2.8 & 12.3 & 7.7 & 190 \\
\hline & Mean & 7.6 & 42 & 2.0 & 1.7 & 1.8 & 18 & 2.8 & 10.3 & 6.2 & 153 \\
\hline \multirow{6}{*}{$\begin{array}{l}\text { Non-man } \\
\text { ure farms }\end{array}$} & Farm 1 & 7.4 & 7.6 & 0.4 & 0.011 & 0.9 & 9 & 1.0 & 4.7 & 3.7 & 72 \\
\hline & Farm 2 & 7.6 & 8.0 & 0.2 & 0.013 & 0.2 & 6 & 1.1 & 3.9 & 2.6 & 77 \\
\hline & Farm 3 & 7.7 & 5.5 & 0.1 & 0.015 & 1.1 & 8 & 1.3 & 4.4 & 3.3 & 67 \\
\hline & Farm 4 & 7.7 & 6.8 & 0.5 & 0.017 & 0.8 & 6 & 1.4 & 2.9 & 4.1 & 50 \\
\hline & Farm 5 & 7.7 & 5.5 & 0.2 & 0.013 & 0.5 & 4 & 1.6 & 3.2 & 3.8 & 78 \\
\hline & Mean & 7.5 & 6.5 & 0.3 & 0.014 & 0.7 & 7 & 1.3 & 3.8 & 3.5 & 67 \\
\hline
\end{tabular}

Soil texture is sand clay loam. 
Table 5. Physical characteristics of soil (mean for each of the 20 plots).

\begin{tabular}{|c|c|c|c|c|c|c|c|}
\hline \multirow[b]{2}{*}{ Main plots } & \multirow[b]{2}{*}{ Sub-plots } & \multicolumn{6}{|c|}{$\%$} \\
\hline & & Sand & Silt & Clay & $\begin{array}{c}\text { Aeration } \\
\text { porosity }\end{array}$ & $\begin{array}{c}\text { Water holding } \\
\text { capacity }\end{array}$ & Total porosity \\
\hline \multirow{6}{*}{$\begin{array}{c}\text { Manure } \\
\text { added } \\
\text { farms }\end{array}$} & Farm 1 & 40 & 10 & 30 & 5.0 & 52 & 30 \\
\hline & Farm 2 & 45 & 12 & 19 & 4.9 & 55 & 33 \\
\hline & Farm 3 & 53 & 17 & 17 & 5.0 & 63 & 31 \\
\hline & Farm 4 & 77 & 15 & 28 & 5.0 & 72 & 30 \\
\hline & Farm 5 & 60 & 14 & 20 & 5.0 & 58 & 32 \\
\hline & Mean & 55 & 14 & 23 & 5.0 & 60 & 30 \\
\hline \multirow{6}{*}{$\begin{array}{l}\text { Non-manur } \\
\text { e farms }\end{array}$} & Farm 1 & 49 & 11 & 23 & 4.4 & 50 & 30 \\
\hline & Farm 2 & 52 & 16 & 15 & 4.9 & 50 & 30 \\
\hline & Farm 3 & 66 & 14 & 17 & 5.0 & 47 & 33 \\
\hline & Farm 4 & 57 & 11 & 13 & 5.0 & 43 & 31 \\
\hline & Farm 5 & 48 & 14 & 11 & 4.9 & 51 & 30 \\
\hline & Mean & 54 & 13 & 16 & 5.0 & 50 & 30 \\
\hline
\end{tabular}

Table 6. Average weather in Kiwere, Iringa.

\begin{tabular}{cccccccc}
\hline Condition & $\begin{array}{c}\text { Dec } \\
\mathbf{2 0 1 9}\end{array}$ & $\begin{array}{c}\text { Jan } \\
\mathbf{2 0 2 0}\end{array}$ & $\begin{array}{c}\text { Febr } \\
\mathbf{2 0 2 0}\end{array}$ & $\begin{array}{c}\text { March } \\
\mathbf{2 0 2 0}\end{array}$ & $\begin{array}{c}\text { April } \\
\mathbf{2 0 2 0}\end{array}$ & $\begin{array}{c}\text { May } \\
\mathbf{2 0 2 0}\end{array}$ & $\begin{array}{c}\text { June } \\
\mathbf{2 0 2 0}\end{array}$ \\
\hline $\begin{array}{c}\text { Temperature } \\
\text { in }{ }^{\circ} \mathrm{C}\end{array}$ & $\mathbf{2 8}$ & 25 & 27 & 26 & 26 & 26 & 25 \\
$\begin{array}{c}\text { Soil pH } \\
\text { Humidity in \% }\end{array}$ & $\mathbf{7 . 5}$ & 7.5 & 7.5 & 7.5 & 7.5 & 7.5 & 7.5 \\
\hline
\end{tabular}

Source: These records are obtained from NOAA's Integrated Surface Hourly data set, falling back on ICAO METAR records as required. Obtained from Iringa Airport and can be supported by a nearby Airport of Dodoma.

evidence of rejecting the null hypothesis that the means of two samples are equal (Results from Table 7).

\subsubsection{Mean Width in Ten Plots}

H0: The means of two samples equal (The mean width of maize plant associated by manure added farms are equal to mean width of maize plant associated by Non manure.

H1: The means of two samples are not equal (The mean width of maize plant associated by manure added farms are not equal to mean width of maize plant associated by Non manure farms). The two sample mean value (variance) are $0.54(0.003)$ and $0.24(0.003)$. the calculated $t$-statistic is 8.66 with its associated $p$ value of two tailed statistic of $<0.0001(2.45684 \mathrm{E}-05)$. Since the p-value is less than 0.05 this provide enough evidence of rejecting the null hypothesis that the 
Table 7. t-Test: two-sample assuming unequal variances on measurements of maize plants in $\mathrm{cm}$.

\begin{tabular}{ccc}
\hline & Manure added farms & Non-manure farms \\
\hline Mean & 212.8 & 107.8 \\
Variance & 77.7 & 97.2 \\
Observations & 5 & 5 \\
Hypothesized Mean Difference & 0 & \\
$\mathrm{df}$ & 8 & \\
$\mathrm{t}$ Stat & 17.75331245 & \\
$\mathrm{P}(\mathrm{T} \leq \mathrm{t})$ one-tail & $5.18508 \mathrm{E}-08$ & \\
$\mathrm{t}$ Critical one-tail & 1.859548038 & \\
$\mathrm{P}(\mathrm{T} \leq \mathrm{t})$ two-tail & $1.03702 \mathrm{E}-07$ & \\
$\mathrm{t}$ Critical two-tail & 2.306004135 & \\
\hline
\end{tabular}

means width of two samples are equal (Results from Table 8).

\subsection{Measurements of Maize Fruits in $\mathrm{cm}$}

\subsubsection{Mean Height in 10 Plots}

H0: The means of two samples are equal (The maize fruits in $\mathrm{cm}$ associated by manure added farms are equal to the maize fruits associated by Non manure farms).

H1: The means of two samples are not equal (The maize fruits in $\mathrm{cm}$ associated by manure added farms are not equal to the maize fruits associated by Non manure farms) the two sample mean value (variance) are 24.6 (1.3) and 0.82 (0.022). The calculated t-statistic is 46.2 with its associated $p$ value of two tailed statistic of $<0.0001(1.3076 \mathrm{E}-06)$. Since the $\mathrm{p}$-value is less than 0.05 this provides enough evidence of rejecting the null hypothesis that the maize fruits in $\mathrm{cm}$ associated by manure added farms are not equal to the maize fruits associated by Non manure farms (Results from Table 9).

H0: The means of two samples are equal (The mean width of maize associated by manure added farms are equal to the maize width associated by Non manure farms).

$\mathrm{H1}$ : The means of two samples are equal (The mean width of maize associated by manure added farms are not equal to the maize width associated by Non manure farms) The two sample mean value (variance) are 0.82 (0.007) and 0.32 (0.007). The calculated t-statistic is 46.2 with its associated $\mathrm{p}$ value of two tailed statistic of $<0.0001(1.29369 \mathrm{E}-05)$. Since the p-value is less than 0.05 this provides enough evidence of rejecting the null hypothesis that the mean width of fruit associated by manure added farms are not equal to the maize width of fruits associated by Non manure farms (Table 10).

\subsubsection{Growth Parameters between Plots and Treatments}

H0: The means weight of maize fruits do not differ in kilograms (The means weight in kilograms of maize fruits associated by adding manure into farms do 
Table 8. t-Test: two-sample assuming unequal variances measurements of maize plants in $\mathrm{cm}$.

\begin{tabular}{ccc}
\hline & Manure added farms & Non-manure farms \\
\hline Mean & 0.54 & 0.24 \\
Variance & 0.003 & 0.003 \\
Observations & 5 & 5 \\
Pooled Variance & 0.003 & \\
Hypothesized Mean Difference & 0 & \\
$\mathrm{df}$ & 8 & \\
$\mathrm{t}$ Stat & 8.660254038 & \\
$\mathrm{P}(\mathrm{T} \leq \mathrm{t})$ one-tail & $1.22842 \mathrm{E}-05$ & \\
$\mathrm{t}$ Critical one-tail & 1.859548038 & \\
$\mathrm{P}(\mathrm{T} \leq \mathrm{t})$ two-tail & $2.45684 \mathrm{E}-05$ & \\
$\mathrm{t}$ Critical two-tail & 2.306004135 & \\
\hline
\end{tabular}

Table 9. $\mathrm{t}$-Test two-sample assuming unequal variances measurements of maize fruits in $\mathrm{cm}$.

\begin{tabular}{ccc}
\hline & Manure added farms & Non manure farms \\
\hline Mean & 24.6 & 0.82 \\
Variance & 1.3 & 0.022 \\
Observations & 5 & 5 \\
Hypothesized Mean Difference & 0 & \\
$\mathrm{df}$ & 4 & \\
$\mathrm{t}$ Stat & 46.24674008 & \\
$\mathrm{P}(\mathrm{T} \leq \mathrm{t})$ one-tail & $6.53799 \mathrm{E}-07$ & \\
$\mathrm{t}$ Critical one-tail & 2.131846786 & \\
$\mathrm{P}(\mathrm{T} \leq \mathrm{t})$ two-tail & $1.3076 \mathrm{E}-06$ & \\
$\mathrm{t}$ Critical two-tail & 2.776445105 & \\
\hline
\end{tabular}

Table 10. Mean widths in 10 plots. t-Test: two-sample assuming unequal variances on mean width (Results from Table 10).

\begin{tabular}{ccc}
\hline & Manure added farms & Non manure farm \\
\hline Mean & 0.82 & 0.32 \\
Variance & 0.007 & 0.007 \\
Observations & 5 & 5 \\
Hypothesized Mean Difference & 0 & \\
$\mathrm{t}$ Stat & 8 & \\
$\mathrm{P}(\mathrm{T} \leq \mathrm{t})$ one-tail & 9.449111825 & \\
$\mathrm{t}$ Critical one-tail & $6.46847 \mathrm{E}-06$ & \\
$\mathrm{P}(\mathrm{T} \leq \mathrm{t})$ two-tail & 1.859548038 & \\
$\mathrm{t}$ Critical two-tail & $1.29369 \mathrm{E}-05$ & \\
\end{tabular}


not differ by non-manure farms).

H1: The means weight of maize fruits differ significantly in kilograms (The means weight in kilograms of maize fruits associated by adding manure into farms differ by non-manure farms). The two sample mean value (variance) are $0.52(0.022)$ and $0.148(0.01052)$. The calculated t-statistic is 4.6127 with its associated $\mathrm{p}$ value of two tailed statistic of 0.002 . Since the $\mathrm{p}$-value is less than 0.05 this provides enough evidence of rejecting the null hypothesis that the difference in the weight of maize fruits in kilogram is associated by manure added farms rather than non-manure added farms (Table 11).

\subsection{Soil Characteristics}

The optimal soil characteristics for better performance of a plant include balanced soil texture, (loam soil), soil pH of between 5.5 and 7.1, soil EC of between 0 and $400 \mu \mathrm{sm}^{-1}$, soil organic matter content (OM) of more than $50 \%$, soil CEC of more than 20 meq./100g, soil $\mathrm{Na}^{+}$of between 0 and $13 \%$, available soil phosphorous of more than $4 \mathrm{mg} / 100 \mathrm{~g}$ and total soil nitrogen of more than $1.5 \%$ [11]. The data on Table 4 indicates that manured soil have a mean of $\mathrm{pH} 7.6, \mathrm{OM} 42$, $\mathrm{N}^{-1} 2.0, \mathrm{PO}_{3}^{-4} 1.7, \mathrm{~K}^{+} 1.8, \mathrm{CEC}, 18, \mathrm{Na}^{+} 2.8, \mathrm{Ca}^{2+} 10.3, \mathrm{Mg}^{2+}$ 6.2, $\mathrm{EC} 153$ and Sand clay loam soil texture. All these chemical characteristics are within the optimal level for the manured soil while the non-manured soil chemical characteristics are not within (poor soil) except for $\mathrm{pH}$ and soil texture which is within the optimal. Data on Table 5 indicated almost the same values for physical characteristics between manured soil and non-manued soil (sand, silt, clay, aeration porosity, water holding capacity and total porosity). Table 6 on the other hand indicated the condition of Iirnga (study area) during the research. This included average temperatue of $26^{\circ} \mathrm{C}, \mathrm{pH}$ of 7.5 , humidity of 87.85 and average rainfall from December 2019 to June 2020 was 5.8 ins or $14.87 \mathrm{~cm}$. All these condition were optimal for growth of Maize as per [9].

Table 11. Weight of maize fruits in kilograms. t-Test: two-sample assuming unequal variances (Results from Table 11).

\begin{tabular}{ccc}
\hline & Manure added farms & Non-manure farms \\
\hline Mean & 0.52 & 0.148 \\
Variance & 0.022 & 0.01052 \\
Observations & 5 & 5 \\
Hypothesized Mean Difference & 0 & \\
$\mathrm{t}$ Stat & 7 & \\
$\mathrm{P}(\mathrm{T} \leq \mathrm{t})$ one-tail & 4.612673061 & \\
$\mathrm{t}$ Critical one-tail & 0.001223615 & \\
$\mathrm{P}(\mathrm{T} \leq \mathrm{t})$ two-tail & 1.894578605 & \\
$\mathrm{t}$ Critical two-tail & 0.002447229 & \\
\hline
\end{tabular}




\section{Discussion}

The results of P-value less than 0.05 on growth parameters of the manured soil against non-manured soil P-value above 0.05 for height, width and weight of the maize plant and fruits (Tables 1-5) and (Photography 1-6) signify the importance of using Cow-dung on the unfertile soil of Iringa. These results agree with the recommendation by [11], [9] and [11] on optimum qualities and value of soil for productive farming. Comparably, most of chemical values in manured soil are above the chemical values of [9] meaning that Cow dung composition has very high level of soil requirements even than normal fertile soil in such a way that can be also used to improve crops productions in fertile soil. Cow dungs are seems to be powerful in supporting soil microbial reproduction and growth which renewals the soil nutrients and Organic matter rapidly hence soil fertility while industrial fertilizers can support crop growth and soil fertility temporarily but kills the soil microbial as they are used meaning that the more the industrial fertilizers are used is the more the soil microbial are killed. Generally, there are triple advantages of using Cow manure which are: improvement of soil nutrient availability, improvement of soil microbial which has a multiple number of uses in the soil and finally improvement of soil fertility [11].

\section{Conclusion and Recommendation}

There are multiple numbers of advantages of using Cow manure in unfertile soil, one is to improve soil microbial production and growth, the second is to improve soil nutrient availability and the last is to improve soil fertility. All three advantages end on improving crop production especially the Maize crop (Photography 1-6). Cow manures therefore are recommended for use not only on unfertile soil but also in fertile soil because it improves nutrients availability in unfertile soil and improves crop production in the fertile soil. Farmers therefore are highly argued to apply Cow manures in their Maize cultivation which can improve productivity and improve soil fertility as well.

\section{Acknowledgements}

It is my pleasure to acknowledge the support rendered by many people whose ideas and knowledge led to the final production of this manuscript. I am grateful to all, though I can only mention a few of them. I give my acknowledgement, thanks and appreciation to my GOD for keeping me healthy by protecting me from all enemies. Secondly, my appreciation should go to my Employer University of Dar es Salaam Mkwawa College for giving me ample time to conduct and write this manuscript. Thirdly, my acknowledgement should go to my colleagues for any assistance gave to me during the writing of the manuscript. Finally, I give my acknowledgement in advance to the Journal which will happen to publish this manuscript.

\section{Conflicts of Interest}

The author declares no conflicts of interest regarding the publication of this paper. 


\section{References}

[1] Ripsudan, L.P. and Gonzalo, G.H. (2000) Tropical Maize Improvement and Production. Thomas Nelson Publishers, Nashvile, 1-87.

[2] Egwim, E.C. and Oloyede, B.O. (2006) Comparison of a Amylase Activity in Some Sprouting Nigerian Cereals. Biochemistry, 18, 15-20.

https://doi.org/10.4314/biokem.v18i1.56386

[3] Sobukola, O.P., Kajihausa, O.E., Onwuka, V.I. and Esan, T.A. (2013) Physical Properties of High Quality Maize (Swam 1 Variety) Seeds (Zea mays) as Affected by Moisture Levels. African Journal of Food Science, 7, 1-8. https://doi.org/10.5897/AJFS11.167

[4] Awoyinka, O.A. and Adebawo, O.O. (2007) Influence of Variety and Malting Period on Alpha and Beta Amylases in Different Nigerian Maize Cultivars. Technical Quarterly, 44, 252-255.

[5] Awoyinka, O.A. and Adebawo, O.O. (2008) Quality Assessment and Potential Utilization of High Amylolytic Nigerian Maize Cultivars. African journal of Biotechnology, 7, 4331-4335.

[6] Dittrich, A.D.K. and Helden, A.J. (2012) Experimental Sward Islets: The Effect of Dung and Fertilisation on Hemiptera and Araneae. Insect Conservation and Diversity, 5, 46-56. https://doi.org/10.1111/j.1752-4598.2011.00133.x

[7] Rupam, J. (2010) Cow Dung and Urine "Healthy". Telegraph.

[8] Bornemissza, G.F. (1976) The Australian Dung Beetle Project 1965-1975. Australian Meat Research Committee Review, 30, 1-30.

[9] FAO (1984) Agroclimatological Data for Africa: Countries South of the Equator. FAO, Rome.

[10] White, F. (1983) Vegetation of Africa. UNESCO, Rome.

[11] Allen, E.S. (1989) Chemical Analysis of Ecological Materials. Blackwell Scientific, Oxford, 368.

[12] Zar, J.H. (1988) Biostatistical Analysis. Prentice Hall, Upper Saddle River, NJ. 


\section{Photography 1-6 (Representative Farms)}

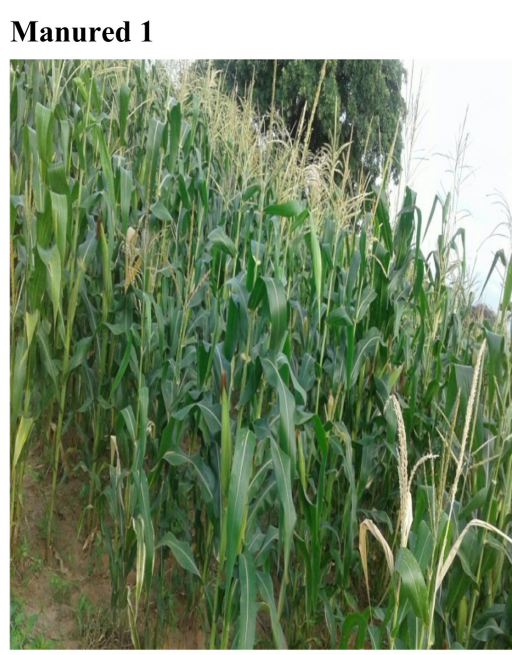

Manure added 3

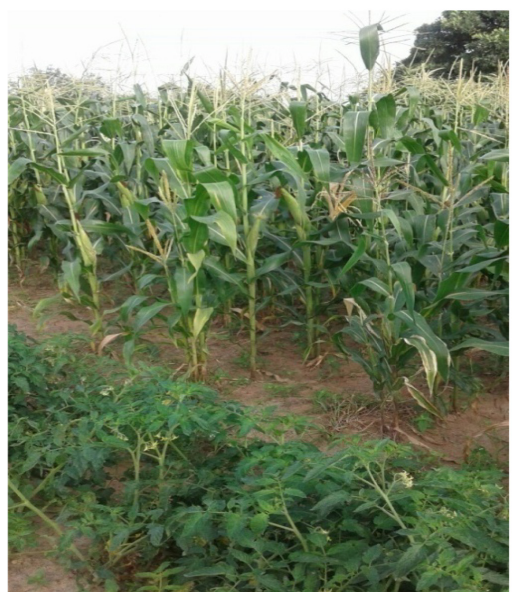

Manure added 5

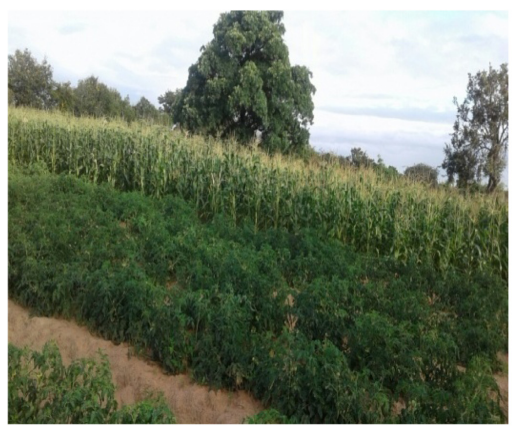

Non manured 2

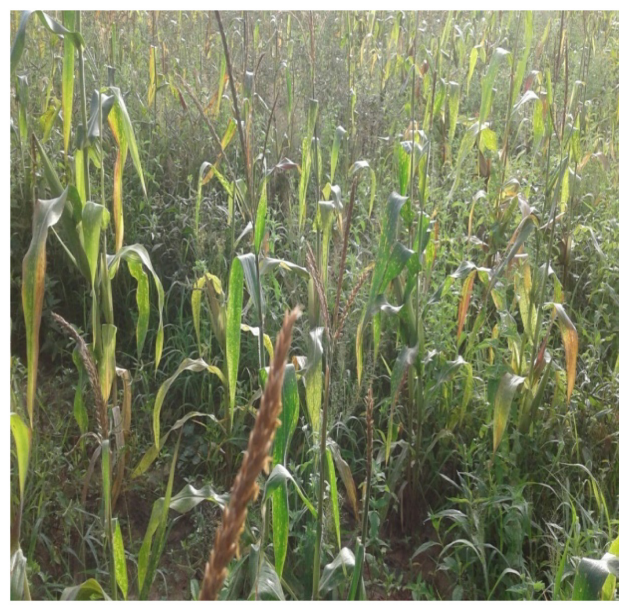

Non-manure 4

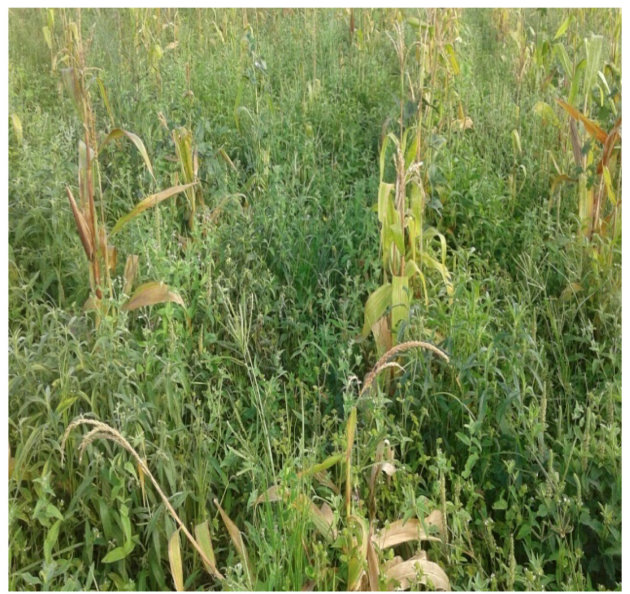

Non-manure 6

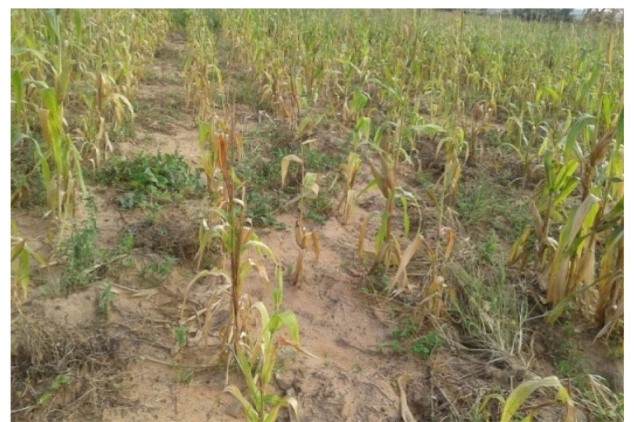

